\title{
Outlining the challenges of Covid-19 health crises in Africa's maritime industry: the case of maritime operations in marine warranty surveying practice
}

\author{
Anthony Djaba Sackey ${ }^{1}$ (D) Bertrand Tchouangeup ${ }^{1} \cdot$ Benjamin Lantei Lamptey $^{2} \cdot$ Bosman van der Merwe $^{1}$. \\ Rapheal Ofosu-Dua Lee ${ }^{1} \cdot$ Robert Mensah $^{3} \cdot$ Musah Chantiwuni Fuseini ${ }^{4} \cdot$ Abigail Dede Sackey $^{5}$
}

Received: 4 January 2021 / Accepted: 25 February 2021 / Published online: 29 March 2021

(C) The Author(s), under exclusive licence to Springer-Verlag GmbH Germany, part of Springer Nature 2021

\begin{abstract}
The relevance of carrying out marine warranty surveys (MWS) as mandatory insurable practice in mitigating associated operational risks within the offshore oil and gas industry, during the Covid-19 crises, was examined against the potential health risk and the various Covid-19 restrictions resulting from newly formed regulations. The health risk concerns to the surveyor and the impact of the Covid-19 policy restrictions for the surveyor's business measured are against the risk of excluding MWS in assessing the suitability of procedures, analyses, and vessels involved in typical offshore marine operations. The purpose of any MWS undertakings ensures that all risks in operations, with potential to destroy property, life, and environment, are minimized - if not eliminated. A series of remote interviews across Africa and direct field observations were respectively conducted at the Takoradi port to develop an understanding of the MWS service product, to ascertain the conditions resulting from current challenges, and to determine contingencies and innovations to ensure full service. The study finds MWS service as paramount to the energy industry with its range of risk control checks for high-value assets and operations. Surveyors demonstrated high-levels of awareness for Covid-19 crises and regulatory policies while in adherence but noted challenges of high-cost and delays as by-products of the restrictions. Surveyors deemed site attendances as crucial in their practice at all time, though recognized the several social and technologically innovative approaches adopted industry-wide to facing the pandemic. The study highlights the need for 'essential worker' status and the introduction of innovative insurance packages.
\end{abstract}

Keywords Covid-19 $\cdot$ Health crises $\cdot$ Policies and regulations $\cdot$ Marine surveying $\cdot$ Maritime operations $\cdot$ Pandemic

\section{Introduction}

The year 2020 in the shipping and maritime industry all across the world set forth with great optimism, at least thus according to accountancy and business advisory firm BDO cited in a January 3rd Seatrade Maritime News online article authored

Anthony Djaba Sackey

deckcadetsackey09@gmail.com

1 DNV GL Oil and Gas/Grassfield Maritime Consultants, Lagos, Nigeria

2 Leeds University, Leeds, UK

3 DNV GL Maritime/Ben Marine Services, Tema, Ghana

4 Ghana Maritime Authority, Tema, Ghana

5 German Institute of Technology, Accra, Ghana by Lee Hong Liang (2020). It asserts these reasons to mark the new decade despite some serious challenges such as compliance with newer environmental regulations (the Environmental Social Governance (ESG), the IMO 2020 fuel price differentials); the geopolitical trade wars and sanctions; Brexit realignment, exchange rate volatilities; and perhaps the need to maintain and increase technical innovation in the ship and engine design (Marcus Hand 2018). The article further noted the high confidence at the end of 2019, which better still reels alongside the general slowdown in global GDP, thus a service in high demand and contractions of new shipbuilding orders.

It was not until March 11, 2020, that maritime and shipping optimism became a mirage - heralding the present. This situation arose after the World Health Organization (WHO) declared the newly discovered Coronavirus strain a global pandemic - fast spreading disease mimicking major world trading shipping routes and immigration patterns across the 
world. The global emergency declaration in effect commenced a series of health interventions and policies by nation-states that naturally can be described as an 'upfront' to globalisation but for the desire to avert possible worldwide health crises. This situation meant a limit to all phenomena with an element of global dealings. Annually, maritime trade contributes $70 \%$ in value to international trade, with national and private seaports handling two-third of its value (UNCTAD 2019). Like the aviation industry, the global emergency did not spare the maritime industry forced to maintain operations in order to sustain the fundamental sanctity of human life with much-needed supplies such as food and health care products.

Today, sub-Saharan African countries are so heavily reliant on international trade to boost and shore-up domestic commodity demands, like the rest of the world are faced with a health crisis relatively unknown at the time of declaration of pandemic by the WHO. Ghana, a case in point, recorded her first active case a day after the March declaration (Ministry of Health (MoH) 2020; Ghanahealthservice.org 2020) by the WHO. The daily situational reports by the then Ghana Health Ministry subsequently led to policy changes and serial implementations of foreign and localised travel restrictions in the country as of March 30, 2020 (GARDAWORLD 2020; U.S. Embassy in Ghana 2020). On March 28, GARDAWORLD reported that Ghana's President Nana Akufo-Addo announced the lockdown of two major regions: the Greater Accra and Ashanti Regions respectively. Unfortunately, for maritime professionals and travellers, the country's largest seaport Tema Port and the airport Kotoka International Airport (KIA) are in the Greater Accra regions. The Takoradi Port which is the second-largest seaport located within the Western region was also however affected by the foreign travel restrictions. Even though the remaining fourteen regions were relatively open with public health mandates actively in place, the situation gradually expanded from health crises to financial, logistical, technical, and psychological nightmares for government, businesses, individual citizens, as well as foreign and domestic travellers. These lockdowns subsequently led to the imminent collapse of businesses, the layoff of employees, loss of capital and investments, cancellation of contracts and forfeitures, fear and panic, supply and demand shortfalls, ill-health, and deaths (ECOWAS 2020a; UNCTAD 2020; STA Law Firm 2020). As the situation developed, ships that already berth in the ports of Takoradi and Tema were forced to limit operations as no ships were allowed in under the emergency government policy guidelines for border controls. The situation observed in Ghana resonated all across the African continent and the rest of the world as media reports suggested - thus rapidly changing with time and data. For marine survey companies and marine surveyors whose job is to inspect and ensure marine vessels, assets and operation undertakings are with eliminated or minimal risk, and the
Covid-19 crises declaration meant a risk to their health while on the field, a loss in business income, travel restrictions, and access restrictions. It also meant a call to embrace newer ways of doing business with innovation (ECOWAS 2020b). The study considers the following as critical objectives: develop an understanding of the marine warranty survey operations impacted by the Covid-19 crises; establish conditions that necessitated possible challenges in terms of policies and regulations implemented at the state, port, and organisational lev$\mathrm{el}$; and determine contingency measures and innovations resilient to meet the demand of unforeseen future crises and clients. Therefore, a resolution of these goals will layout a foundation for ensuring that marine surveying remains optimal in the face of potential future crises. This study is warranted because findings will reveal the real challenges experienced in Ghana and for that matter Africa's maritime survey industry. It will also help inform future policies and regulations while advising on the best approach to balancing costeffectiveness and sustaining high-integrity operations in emergency settings.

\section{Literature review}

\section{Overview of marine surveying industry}

The rich diversity in the global maritime industry today in terms of product and services according to Lloyd's Maritime Institute (LMI) (2018) pp 1), 'opens up a large number of potential areas of surveying for professional marine surveyors'. However, the type of survey and type of surveyor needed for the specific marine venture depend on the instructing party they further added. These specialisations against demand also presuppose that $m a$ rine surveying undertakings - in business terms, also depends on a specific type of client. Learn.org (2020) explained the term marine surveying as a 'practice of inspecting marine equipment, primarily boats and cargo, to determine the safety and market value'. Thus, a marine surveyor is either called to assess a damaged vessel for insurance purposes, appraise a vessel sold, or serves as an expert witness in litigations (Learn.org 2020).

LMI (2018) notes that the marine survey industry comprises various segments of marine surveyors, which in simplest terms, groups into two specific types, namely, those servicing the leisure or pleasure boating market and those engaged in the global commercial marine market. This distinction however does not limit surveyors whose background and expertise place them in both markets. LMI (2018) and Learn.org (2020) therefore reiterate the further divisions in the survey profession and business owing the various specialisations developed through personal background, knowledge, and experience. Education, training, and qualification are essential in this regard (LMI 2018). 
Imperatively, the surveying business setup structure according to Learn.org (2020) widely comprises independents (also referred to as freelancers), local marine surveying businesses, and professional organisations, such as the International Institute of Marine Surveying (IIMS) and the International Association of Marine Consultants and Surveyors (IAMCS). These professional associations go a long way to provide some form of cover for quality and training of their surveyors in meeting current standards. Among these pool of surveyors are those who also serve as statutory or regulatory inspectors. These include the governmentcontracted port state control inspectors or agent, auditors, flag states, court-appointed witness, accident/ incident investigators, and classification societies (LMI 2018). Generally, the group or organisation a surveyor belongs to may determine how his or her liabilities are covered in the discharge of their duty. The situation is worse in the case of freelancers or small survey business holders with little to no insurance cover during their survey practice. This notwithstanding, surveyors remain relentless at their duty to provide the needed risk assessment and protection for asset owners and stakeholders.

The final group of marine surveyors which is of great interest to this study are the marine warranty surveyors (MWS). These surveyors, as their name imply, are tasked with surveys that secure insurance warranties basically within the offshore industry. Their business model and background are in proceeding paragraphs.

\section{The marne warranty surveying}

Although the maritime and offshore industry describes the two major segments of the global commercial marine market, their operational interface is intertwined. Generically, the maritime industry or market simply referred to as traditional commercial marine ventures is dedicated to the transportation of cargo. In other words, it is a business that deals with ordinary carriage of goods from one port to another for affreightment. This traditional role therefore defined marine vessel designs in terms of the types of cargo carried. LMI (2018) lists the major commodities in seaborne trade as crude oil, oil product, liquified gas, chemicals, coal, iron ore, grain, fertilisers, and bauxite. Whether as finished or partly finished goods, these various traditional commodities have over the years defined the various cargo carriers, such as bulk carriers and containerised vessels (LMI 2018). They further assert that particular areas within the seaborne trade require special attention and list the carriage of cars, heavy lifts, and livestock, and the need to undertake engineering work away from shore in order to bring energy suppliers across the world. The latter practically refers to as the offshore marine industry. Historically, offshore energy industry began in America and dated back to the 1890 s, when the first so-called offshore rig was installed $90 \mathrm{~m}$ off the Californian coast. Today, these highly specialised seaborne transport operations therefore made use of specialised vessels with powerful capabilities like seismic survey, pipe-layers, heavy-lift installers, anchor handlers, ROV support vessels, cable layer, platform support vessels, diving support vessel, flotels, mobile offshore drilling units (MODUs), and floating production storage and offloading (FPSO) units. Like any other seaborne trade, this specialised industry is also rapidly evolving with innovation and marine technological assets (LMI 2018). The quest for greener energy supply is setting the stage for the change from fossil fuel to the wind (GWEC - Global Wind Energy Council | Disclaimer 2020), hydrogen, and solar farm offshore (DNVGL 2020). These highly technical engineering operations are financially intensive; hence, assuring investors and insurers of safe operation is a task mandated to the marine warranty surveyor.

In the words of TÜV-Rheinland (2013), 'in order to prevent loss or damage to your marine installations, we provide offshore installation companies, insurers, energy companies, oil and gas companies, and freight forwarders with extensive Marine Warranty Survey (MWS) services.' They subsequently defined and explained MWS as 'the supervision of marine operations on behalf of a client and according to the insurer's interests (2013 pp1).' Naturally, an insurer requests for an MWS. This request registers in their warranty clauses between the insured and insurer. Nonetheless, there are occasions when there is no request from an insurer for an MWS. In this case, most owners and operators take it upon themselves to make a request (LMI 2018; TÜV-Rheinland 2013). In understanding the role of MWS, the proceeding paragraphs do make references to some commonly used terminologies such as marine warranty, suitability survey, off-hire survey, on-hire survey, review of certificates, review of documents and calculations, and certificate of approval, which underpins the MWS operations in regard to the given scope. All these specialised tasks place the MWS in close proximity vessels and operationsrisking their exposure to the global health crises and infection.

\section{Importance of marine warranty surveys}

Regardless of the Covid-19 crises, the marine warranty surveyor must ensure the safety, reliability, and compliance of the installations operations with applicable standards. This task gives client confidence of having a warranty in case of damage or loss of the structure or assets. Therefore, according to ASME (2004), the role and importance of marine warranty surveyor are often misunderstood by the participating personnel involved with the marine and offshore engineering projects. With a lack of understanding of their role by the personnel involved on project sites, they are perceived as 'unnecessary nuisance' by some. Again, roles of MWS are frequently confused with roles of the classification societies, such as ABS, DnV, BV, L.R., and other 
certification verification agents (CVA) who were formed in the early stages to provide a standard of primary ships designing and construction. As their experience grew in engineering principles and empirical formulations, they developed rules and guidelines for designing ships (ASME 2004). ASME further asserted that the early days of major MWS activities were limited to selection of ships and tugs for cargo transport, approving loadout, lifting, offloading, and sea fastening operations during transportation. The surge in marine activities on installations of offshore structures further broadened MWS activities considerably, to encompass operations unique to offshore structures. This modification over the year has standardised into outlining (a) the scope of MWS services, (b) MWS activities, and (c) requirements and criteria of selected items.

The Joint Rig Committee Rig Move Code of Practice ${ }^{1}$ (COP) (2016) also clarifies the role of an MWS as one making every reasonable endeavour to ensure risks associated with insured operations to which they are appointed reduced to acceptable levels based on best practices. According to them, the assigned task therefore implied a timely fashioned attendance, provision of full information, and more explicit recommendations. Where the MWS Company is of concern, it does appoint only persons with demonstrable competence, qualification, and experience, and perform review/approvals in line with scope of work (SOW). Overall, the MWS is obliged to specify recommendations to be met in minimising risk, ensuring the satisfaction of operations as following possible code of practices, approve operations manual, industry-wide best practices for the particular insure unit, equipment and vessels.

In other words, in carrying out a proper MWS service, any approved marine operation should have no considerable risk to property damage, loss or injury to human life, and the environment in general, according to ASME. Notwithstanding this condition, all marine operations naturally carry some level of 'risk' or element of risk. Therefore, these risks need to be 'as low as reasonably practical' (ALARP). M.W. surveyor must recognise there are no contractual relations between the marine warranty companies' assured contractors, such as tug operators, riggers, shipyards, installation contractor, and designers, and hence instructions of any form cannot be issued to them (ASME 2004).

\section{Marine Warranty Survey Operations and the Concern for Site Attendances}

Generally, typical marine operations cover some activities undertaking on land or shore base. Examples of such include the lifting of cargo from queue side and worksite (yard), the transportation of cargoes on a trailer or SMPT trucks, and pulling

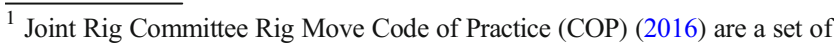
responsibilities ad obligations to be met by the MWS. [Refer to Joint Joint Rig Committee Rig Move Code of Practice (COP) (2016), Doc. JR2016/012: Rig Committee Rig Move Code of Practice (COP) and Rig Move Warranty Survey Scope of Work, for further reading].
}

and sliding cargoes with or without using jacks. These operations need approval (thus the issue of a COA (Certificate of Approval)) by designated MWS for insurance coverage. Therefore, any operation without MWS's approval and presence is a breach of warranty-allowing the insurance coverage may lapse (ASME 2004). The following are a brief of standard MWS operations of interest to this study per DNVGL-ST-N001 ${ }^{2}$ guidelines.

Suitability survey (S.S.) The suitability survey (S.S.) is a survey activity intended to assess the suitability of the vessels, tugs, barges, and equipment for planned usages. According to ASME, the MWS conducts this type of surveys to assess a proposed vessel for certain operations, to include but not limited to, "cargo transportation, the capability of a tug for towing a cargo barge, launching a Jacket platform' (2004 pp2). During the assessment, the surveyor will use all the pertinent project information, e.g., transportation route, bathymetrical data of the route, and weather condition during tow (ASME 2004). The nature of the task most likely places the surveyor on the attending site where he or she may come in contact with marine crew-exposing them the covid-19 health risk.

On-hire and off-hire surveys Such survey usually is not included in marine warranty unless specifically expressed. It compares vessel condition before and after a specific mission to determine if there was any damage to the vessel throughout the marine operation. In this case, the vessel owner mostly uses another surveyor for the assessment (ASME 2004). The task also does place a surveyor on site for attendances.

Review of certificates The extent, in this case, depends on the specifics of the marine operation (i.e., winches, valid classification certificates, bollard pull certification, certificates of crane and crane capability chart, shackles, slings, pin, jacking system, mooring ropes (wire or chain), weighing certificates, any test certificate) (ASME 2004). These task relatively can be carried out remotely on short notice.

Review of documents All relevant documents such as stability letter provided by regulatory agencies, periodic and annual survey reports provided by the classification society, including the review of all relevant marine procedures (thus, loadout, ballasting and deballasting plans, rigging plan, launching, and installation). The extent, however, is marine operations specific (ASME 2004).

Review of calculations encompasses calculations of pile driving, the structural integrity of cargo as well as vessels, on-

\footnotetext{
${ }^{2}$ DNVGL-ST-N001: is a guideline document composed as a standard for all MWS practice. Refer to DNVGL-ST-N001: Guideline for Marine Operation () for further reading.
} 
bottom stability, lifting, mooring arrangement during loadout, berthing condition before sail-away, ballasting, bollard pull, sliding, seakeeping, and design of sea fastening and structures (ASME 2004). This operation does not readily need site attendance by a surveyor.

Certificate of approval (COA) By issuing a COA at the commencement of each marine operation, it is implied the MWS company acting through the attending surveyor finds the proposed marine operation acceptable after review of all relevant documents, procedures, certificates, and calculations. The acceptability also hinges on complying with best industry practices, regulations, codes, criteria, and sound engineering principles. Any operations without a signed COA or unconsented deviation from the approved operation of attending surveyor may result in a breach of warranty (ASME 2004).

In summary, none of this traditionally assigned task is effectively achieved without an attending surveyor. However, there has been a growing interest in remote surveys under special circumstances. This situation therefore places enormous health, safety and environment (HSE) risk on such appointed individual in attendance, who are obliged to comply with both site HSE regulations as well as company regulation at the onset of strains of the new coronavirus cases reported worldwide (with the limited knowledge at the time on the mode of transmission and the extent of lethality). Nonetheless, there was a dramatic impact on all industriesnotable among them is the situation of seafarers across the world for whom MWS work alongside during ships' port calls, drydocks (ship), and also during operations at shore and offshore facility locations (U.N. Chronicle 2020). The global pandemic has therefore put great constrain on seafaring, one of the world's fundamental trade supporting human existence. In understanding what ways the health crises is transmitting on the maritime industry detail understanding of the Covid-19 virus cycle upon infection and its impact (health crises) is briefly explained below.

\section{The Covid-19 virus and the health crises on the mar- itime industry}

According to Thetius (2020), the new Coronavirus was 'causing significant problems for the maritime industry, with volatile supply and demand, port closures, and difficulties with crew changes.' The March 11, 2020, declaration of pandemic sets in motion series of localised and international restrictions - what the Secretary-General ${ }^{3}$ (S.G.) of IMO said amounted to large numbers of seafarers extending their

\footnotetext{
${ }_{3}^{3}$ The IMO Circular Letter No.4204/Add.14/Rev.1 5 October 2020, with SG Discussing the subject of the pandemic, thus Coronavirus (COVID-19)Recommended Framework of Protocols for ensuring safe ship crew changes and travel during the Coronavirus (COVID-19) pandemic
}

onboard service ships indefinitely at sea, without the possibility of a crew change.

Briefly, the World Health Organization, WHO (2020c), the John Hopkins University, the John Hopkins Hospital, and the John Hopkins Health System (2020) describe the coronaviruses as a type of virus that emerged from China in December 2019. Currently, there are many different kinds of which some cause infections. According to them, the newly identified SARS-COV-2 (also widely referred to as Covid-19) is the cause of the worldwide pandemic of respiratory infections. They list the symptoms to include coughs, chills, or fever; shortness of breath or difficulty in breathing; muscle or body aches; sore throat; loss in taste or smell; diarrhea; headache; fatigue; nausea or vomiting; and congestion or running nose. Some case infections can be severe and lead to eventual death. The spread of the disease is from person to person and can only be diagnosed with laboratory testing. There is a raise to have a vaccine. However, the current treatment has been by therapeutic drugs and nutritional supplements (WHO 2020c; The John Hopkins et al. 2020). As of October 18, 2020, the global cumulative figure of infections stood at $40,118,333$ with a six (6) per cent change over the last 7 days. The Covid-19 deaths also stood at 1,114,749 (WHO 2020a). All these stats receive a daily update. John Hopkins et al. (2020) therefore concurred with the WHO (2020b) that prevention of infection and its spread would involve the use of running water with frequent hand-wash, bending your elbow over when coughing, staying when sick, and wearing a cloth face cover where social distancing is impossible. These basic personal hygiene principle which mostly was a matter of individual discretion had overnight assumed a legal mandate - changing the phase publicprivate interactions. The news of Covid-19 recorded cases on cruise and military vessels in the early days was at the heightened fear within the marine industry since seafarers interact with other marine professionals at the time.

Therefore, for the maritime industry of which seafarers are at the centre (World Economic Forum, WEF 2020), the challenge from the Covid-19 impact can be segregated into three distinct folds, namely, (i) providing health and safety protection for the crew and vessel, (ii) ensuring the crew are not marooned (K. Whiting 2020) - affecting their mental wellness, and (iii) preventing the global supply system from grinding to a halt (K. Whiting 2020). Thus, they are interrelated, except under certain circumstance. Radic et al. (2020), examining the psychological effect on employees of a cruise ship, reiterated that besides the direct health implication on contracting Covid-19, depression was a profound medical illness that negatively influences how an individual feels, thinks, and acts. Ultimately, it leads to sadness or deprivation of delight in previously pleasurable activities (Parekh, K n.().; Radic et al. (2020)). Seafarers are susceptible to diverse mental health disorders including depression (Sau and Bhakta 
2019; Radic et al. (2020)). Radic et al. (2020) found the condition depression to be the case in their study coupled with poor human resource management strategies that lacked a contingency plan in managing health and epidemiologicaltype crisis such as the Covid-19, also bearing in mind that social isolation robustly contributes to depression (Alpert 2009; Radic et al. 2020). The situation of maroon was pervasive and according to Dolven, close to 100,00 cruise ship employees are stuck at sea for months (Dolven 2020; Radic et al. 2020) due to the Covid-19 pandemic. K Whiting (2020), IMO, and the United Nations Conference on Trade and Development (UNCTAD) also suggested that as of midJune, 300,000 seafarers per month needed scheduled international flights to enable crew change. The International Maritime Organization, IMO (2020), estimates that as of December 2020, 400,000 seafarers currently remain stranded on ships beyond original contract duration and were unable to be repatriated, while suggesting similar numbers were stuck at home, unable to rejoin ships and provide financially for their families. Of the direct health impact by the crises on the seafarers, the US CDC (2020) indicates, where ships were of concern, the Grand Princess was the first reported while over 700 people becoming infected on Diamond Princess and 10 people dying. At the time, the case accounted for over half the reported cases of SARS-CoV-2 outside of mainland China (Wikipedia 2020). Several cases of infection from cruise ships since then have been reported across the world to include vessels like World Dream, Celebrity Apex, and Greg Mortimer. Other vessels affected include several FPSO units and Rigs in the offshore oil industry such as FPSO Kwame Nkrumah with 60 case infections from the accommodation FPSO unit (Eoin O'Cinneide 2020), and Shell's Nelson rig which recorded fourteen cases of infection (BBC 2020). With rising case infection globally, the new challenge sets forth a series of restrictions which meant business, including MWS, and their customers had no option but to adapt to the changing environment of regulations. The detail of these health policies and regulation in the aftermath of Covid-19 is explained below.

\section{Covid-19 regulation and policy implementation}

Since the onset of the virus, several regulations and policies worldwide have been put in place to curtail its spread. These regulations and policies (both local and international nature) are guided by the WHO's mandate to member states. Thus, the WHO continuea to issue policy guidelines for member states (WHO 2020b, c) who, in effect, implement the thorough domestic policies and regulations. The regulations though varied in the extent of implementation and timelines across the world, they can be grouped into (a) movement or travel restrictions and (b) public order mandates (a) Movement or travel restrictions: as its name imply, it restricts the movement of persons from place to place. In Ghana, the restriction of movement came into force through the Imposition of Restrictions Act, 2020 (Act 1012). The Government of Ghana through the president, briefing the public on the Covid-19 update, announced closures of land, sea, and air borders to foreign nationals effective March 16, 2020 (KPMG-Ghana 2020). The Act saw the implementation of regional lockdowns of two major cities, Greater Accra, and Ashanti regions as early as March 2020 (MyJoyOniline 2020). Besides the subsequent border closures for locals on March 22, 2020, there were curfews and 14-day mandatory quarantines for returnees. Similar laws were formulated and implemented across most nations of the world except for the four countries ${ }^{4}$ that did not shut down.

(b) Public order mandates: includes social distancing and other restrictions and behavioural mandates. In Ghana, the social distancing mandate, implemented based on Act 1012, required individuals to stay $2 \mathrm{~m}$ apart in public spaces. There was also the mask-wearing mandate which followed the public order act. The mask mandate came into effect on April 22 (GARDAWORLD, 2020). The public order act included a ban in public gatheringeven so, restricted to a maximum of 25 people, the shutdown of educational institutions, a required personal hygiene mandate for essential public institutions, reduced passenger intake in public transport, and business and workplace prescribe mandates for operation (KPMGGhana 2020).

\section{The work relationship between the MWS and the ordinary seafarer at the center of global Covid-19 crises}

The challenges seafarers have faced and continue to face during the global pandemic are at the core of the complex global supply chain, which Kate Whiting (2020) suggested could grind to a halt without them, while alluding to the fact that merchant ships transported $90 \%$ of global trade by volume from food and medical goods, energy and raw materials. The seaworthiness of the vessel and vessel suitability for work task has remained paramount regardless of the many restrictions established to limit Covid-19 spread. This requirement places the MWS at the centre of operations amidst the pandemic crises. The situation is exacerbated when an appointed attending surveyor is placed on vessel sight—risking himself

\footnotetext{
${ }^{4}$ Countries that did not shut down include Sweden, Japan (The Asahi Shimbun, May 1, 2020: the Japans State Of Emergency Is No Lockdown. What is In It?), and South Korea (Time, May 1, 2020: How South Korea Is Beating Coronavirus Without A Lockdown) in Asia, and Nicaragua (Foreign Policy, April 25, 2020: Nicaragua Is Stumbling Into Coronavirus Disaster).
} 
and crew of infection. Given that the Covid-19 case count continues to rise among marine vessel crew (BBC 2020; Wikipedia 2020), the inherent risk to marine warranty surveyors is fairly established and there is a clear need for remediation.

\section{General challenges and innovations against continuous operation}

In all, these changes do have socioeconomic, political, and cultural implications on individuals and the nation as a whole. Some of the fallouts according to media reports have been the loss of jobs, slash on incomes (MyJoyonline 2020), loss of investments, the collapse of businesses, loss of capital, inability to maintain the competent workforce, suspension and cancellation of contracts, price hikes, and high cost of operations. There is also the psychological impact on people's mental health (Maekelae 2020; equalityhumanrights.com, September 22, 2020). Broadly, the WHO affirms the implications though encompasses every sector of a nation's life; it was an unavoidable consequence given the threat (WHO 2020b).

Despite the difficulties, the maritime technology community fights back against the virus, with several startups, tech companies, and other business launching services or providing data to help the industry cope with the strain (Thetius 2020). In August 16, 2020, a seminar held by the Maritime Standard on the topic 'Offshore Oil and Gas sector adapting well to Covid-19 challenges' (Naterer 2020) and reported in the Latest Maritime \& Shipping News Online highlighted how the industry adapted to the crisis through the acceleration of digital technologies, including remote inspections and AI-driven operations. The others include the successful integrated working from home practices, despite the inevitable challenges posed in the particular sector. According to the Maritime Standard, the offshore, oil and gas sector is vital to economies of the Middle East and Indian subcontinent. The situation also spared the offshore oil and gas supply chains to adapt to transitional energy markets emerging; as a result, the drive to develop sustainable green energy sources (GWEC - Global Wind Energy Council 2020; The Maritime Standard 2020).

\section{List of notable technologically drive innovation}

Thetius (2020) proceeds to list some of the innovative support implemented in the maritime industry in general (Douglas et al. 2020). These are as follows. The Wilhelmsen Ship Services launched a Global Covid-19 Port Restriction Map, providing details of active restrictions and special requirements for ships sailing to ports around the world. The Israeli tech scaleup Windward launched a map proving the maritime industry keeps the world afloat. The geophysical technology company ION also offered ports like their Marlin SmartPort solution for free use over 3 months - helping disseminate information while easing the strain on communications resulting from working remotely. Inchcape World of Ports in partnership with PortXchange launched Stay Healthy and Connected initiative to offer ports free access software during the crisis. The maritime satellite provider Inmarsat offered 50\% discount on voice calls for seafarers plus, in partnership with Vikand and FrontM, free video call service for seafarers with the desire to speak with a trained health professional. Crew health and wellbeing software startup. Big Yellow Fish temporarily offers free access to their human element and wellbeing monitoring software to support seafarer mental health. The digital publication and solutions provider OneOcean has made a comprehensive list of national and international Covid-19 documentation available for free (Thetius 2020).

\section{Research methodology}

\section{Study design and scope}

The study herewith proceeds following a case study approach in developing an understanding of the subject under discussion by combining information gathered with ideas generated - informing the knowledge base. Though Ghana's maritime operations, in general, is at the centre of concern due to ongoing Covid-19 public health restrictions across the country (including marine facilities), researchers' own imposed risk limitations as well as limitations of the affiliate marine survey organisation, the study limits scope to two operations (one involving regional travel on the continent, and the other being domestic) assigned to the marine warranty surveyor (MWS) under study. Concurrently, the scope is limited to the African surveyors. The scope will also evaluate MWS operations observed by researchers during offshore surf operation (Haynes et al. 2020) undertaken by other Ghanaian and foreign surveyors within Ghana before Covid-19. The scope chosen is in sync with the general business trend within the industry by clients relying on MWS regardless of their location for assets and operations integrity assurances. The approach will primarily be qualitative in the description.

\section{Structure of the study}

The study structure comprises of the two distinct activities described below. It proceeds to examine the entire African context soliciting experience of a select group of MWS available to the researcher. It then makes use of a narrative element in describing the two subjected site attendances under study.

\section{Sample size}

The sample chosen for this study is a fraction of the marine survey and offshore engineering community across Africa 
with a varied degree of experiences in survey practice and client representation. All ten (10) expert respondents were engaged in interview sessions. The size chosen took into account the distribution of MW surveyors whose practice are within the various regions of Africa. However, one declined to participate due to personal reasons. Table 1 below is a list of crucial experts interviewed.

Data gathering process the data gathering process following a case study approach acquired various forms of data implementing various sets of tools at the researchers' disposal. The study factored in restrictions, time, and access during the gathering process on both spent on the field. These considerations significantly impacted on the primary data collection process and its sources. Tools implemented in the primary data gathering process included but not limited to interviews, referral to internal documents, and site observations. Direct and indirect interviews were conducted (see Appendix).

Data analysis process the data analysis carried out on the data gathered from the study, which was mostly qualitative, followed a descriptive narrative while employing comparative arguments towards developing the knowledge from information obtained. The architecture (shown in Fig. 1), similarly, is a slight modification of Sackey and Lamptey (2019), and Ellinor (2013) structure and thus incorporates the global health challenges into the general understanding of operations, regulations, and the dynamics of geopolitical climates.

\section{Results, analysis, and discussion}

Results presented examine the two cases of MWS attendances with expected completion during the Covid outbreak in Ghana and Nigeria. It also discusses the experiences of other marine survey attendances per selected experts and sample for interview. The discussions are detailed below.

\section{Background of respondent}

In all, the experiences of the nine respondent accumulates into 82 years from which six (6) seasoned contributed about seventy (70) of the total. These seasoned respondents were within the work brackets of senior management and principal consultancy who largely made decisions that affected the work scope of junior surveyors under their supervisions over the period.

\section{Situational awareness by respondent}

When respondents were asked if they were aware of the Covid-19 virus, the symptoms, the protocols in place at the worksite, and if they are ever willing to help to end the spread, the respondent showed high levels of awareness for the Covid health crises. At least each respondent could catalogue several symptoms to look out for when they scan their nearest environment. They were also aware of the very immediate protocols in place at attending sites and how to effectively contribute to minimising the spread among crew. Though surveyors are third-party crew aboard, according to all respondent, they never felt they were not part of the fight and were ever ready to help whichever way they could. According to them, they particularly empathise with seafarers, who have been forced to overstay their contract time onboard. They highlight situations wherein in reviewing seafarer documents found many were obviously out of date; however, recognizing the peculiar challenge does not enforce documentary restriction based on IMO emergency circular issued for the expired certificate in this regard.

\section{The MWS practice}

On the question of whether MWS site attendances should be halted and surveys are limited to only remote operations, the respondent pointed out that it was impossible to have MW site attendance practices cease on the advent of the Covid-19

Table 1 Sample interview respondent

\begin{tabular}{llll}
\hline Institution name & Resource person & Date & Scope \\
\hline DNVGL Oil and Gas, Nigeria & Principal marine surveyor & $24-10-2020$ & MWS survey \\
DNVGL Oil and Gas, South Africa & Senior marine surveyor & $24-10-2020$ & MWS survey \\
Subsea 7 Engineering Limited, UK & Deck crew & $15-09-2020$ & Marine offshore \\
Subsea 7 Engineering Limited, UK/BELMET 7 & Company representative & $(15-18)-06-2020$ & Assets and operation \\
Bourbon Offshore & Vessel management team & $15-06-202$ & Ship management concerns \\
Dynamic Marine Survey and Solutions & Marine surveyor & $28-10-2020$ & Survey concerns \\
Trans Africa Correspondent Group, Liberia & P \& I surveyor/cargo & $10-10-2020$ & Club survey \\
Ghana Maritime Authority & Statutory surveyor & $20-10-2020$ & Statutory \\
IGK Global Logistic Service, Nigeria & Marine cargo surveyor & $18-10-2020$ & Cargo \\
\hline
\end{tabular}




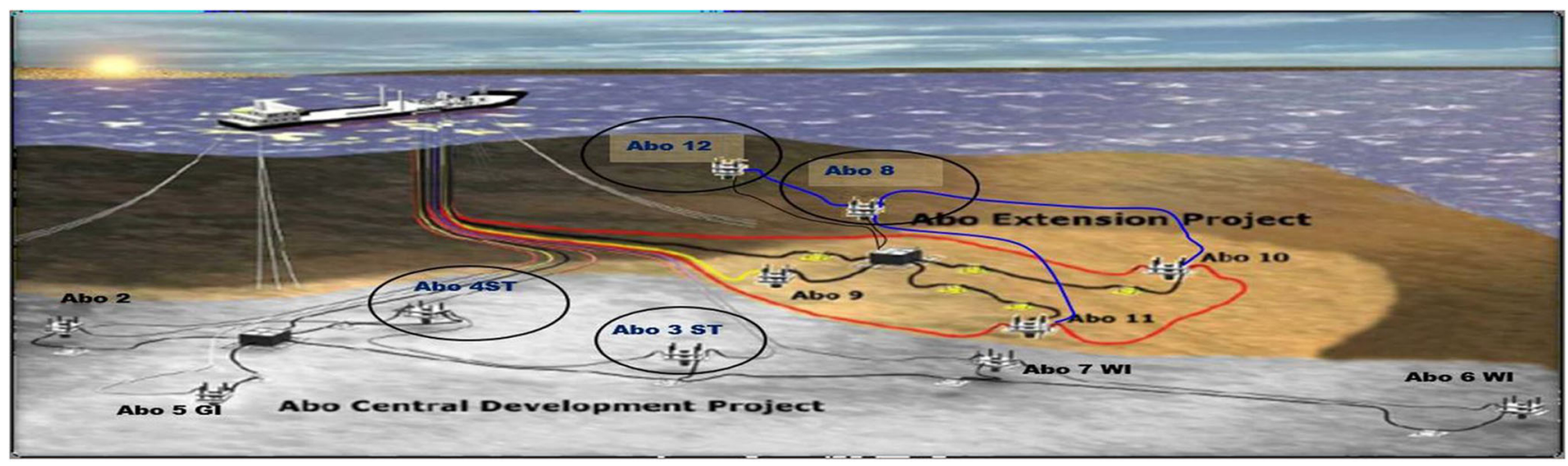

Fig. 1 Layout of the ABO Oil Field. Courtesy; CNS-NAE (2020)

restrictions and risk of spread of infection. Respondents contend that though everyone will agree that continuing business as usual meant taking an extreme risk, they contend their job was a noble one that ensures the safety and therefore could not be left to only remote services. For example, they noted that regardless of the Covid-19 pandemic crises and restriction, marine vessels and operations have continued to be in operation. There are also records of safety incidences and marine property loss across the world at sea. In Africa, a respondent pointed out to the recent incidental loss of an offloading pipeline under construction that happened on the Jubilee field of the FPSO KNK unit in the month of September 2020. According to respondents, such an incident cannot be investigated remotely to the satisfaction of the client or anyone for that matter without the direct presence on site of incidence. They, however, agree to the assertion that the use of remote service in their operation is limited to peculiar surveys and was rare. As to its effectiveness, the respondents were reluctant to answer and when they did, felt the cost-benefit analysis will only be properly assessed after a long time in operation. Thus, as things stand, most offshore operations or projects have been cancelled and therefore limiting the services of MWS operations at both onshore and offshore locations. From their comments and discussion, there was a clear to desire or sentiment to have processes return to normal.

\section{Health risk and site attendance}

Respondents were asked whether in any of their attendances they had in any occasion tested positive or attended to a vessel whose crew might have tested positive; all respondent answered to the contrary - having received negative PCR test on such occasion - insisting Covid-19 protocols were strictly adhered by both attending surveyor and vessel support crew. Others respondents stated that though they cannot point to any individuals they might have met during site attendance who had Covid-19, they believed the risk was imminent and did not take any chances of disregarding laid down MWS Covid-
19 protocols from both the clients and MWS company. Again, when asked whether they will attend to a vessel with a previously known positive case for Covid-19, the respondent explained that with the given knowledge at the hand of the viruses' mode of operation, and the record of treatment, they had no reason to forgo any attendances because of past cases - suggesting its reason for the protocol of quarantine

A follow-up question as to whether they deem site attendances as an essential business and the need to be recognized as such, the respondent was certain and found it disappointing that this has not been the case all this while. According to them, seafarers and marine businesses have continued to operate not because they did not find the risk dangerous to their health and people around, but that the seafaring trade remains the lifeline to the global supply of essential commodities like food, medicine, energy, and utilities needed in the fight even against Covid-19. Respondent believes the call for a certain maritime professional to have the status of essential workers in the fight against the pandemic is long overdue, and it was high time the IMO provided that technical guidance to its member state. They contend such a policy could come with added protocols in order to facilitate the process. Further studies would be required in order to have a full-scope understanding of surveyors who suffered from Covid-19 in the cause of duty.

\section{Regulation on travel restriction}

The respondent was further asked whether they found the national and international protocols tough or mild on their operations; they indicated that the current regulations were tough as much as they can be; however, they accepted them as the crises showed no end in sight. According to them, though no business in its right sense agrees with any form restrictions that will hamper profitability and survival of a business, the Covid-19 situation was one of the rare events - though would hope never to repeat. The respondent suggests great lessons have been learnt and do hope after the end of these crises, going forward, they can provide great 
insight to help policymakers to better prepare in any future challenge-while itemising some general sentiments they have picked up talking among their customers and colleagues.

\section{General sentiments of restrictions to operations and the Covid-19 health risk in maritime businesses}

Loss of business and income On the backdrop of the cases highlighted above, questions ask of impact on business in the industry revealed that the market had been slow even on recovering after several months-living with the virus. This negative report was a general sentiment expressed by all expert surveyors interviewed. While other surveyors felt there is the need to consolidate the shortfall in income with lower than average quotations in order to put food on the table for the family, others felt this was a sign of weakness which implied altering the industry financial structure and quality of service. The difference in opinion one could easily infer to the organisational structures these surveyors belonged. Thus, surveyors of well-established multinational institutions (such as Global Maritime, DVN GL Oil and Gas, ABS) felt protected by the caps their institutions determined over a range of price quotations. This sentiment expressed was not the case for small marine companies. There was all the concern of companies taking advantage of the Covid-19 restriction chaos to disregard the much-needed surveys or where the case may be resort to freelance surveyors whose qualifications cannot fully be verified. Again, with offices closed, others have resorted to operating as freelance surveyors or from home offices.

Project cost escalation Respondents were of the view that the cost of projects was going to rise as a result of both movement restrictions and the risk of contracting the virus during attendance. It is unclear how much of these concern is factored into insurance cover of this survey companies since the viral infection is relatively new. The high cost, according to respondent, emanates from the increased personal protective equipment wears, cost of Covid-19 testing from test centres, and the cost of innovations implemented to service the needs of clients.

Project delays Most respondents affirmed that delays are a part of operations following the Covid-19 outbreak. However, according to them, it has not impacted much on the quality of service clients demand of them. Mostly, the case of delays may arise, for example, where mandatory quarantine required is before mobilisation. The respondent highlighted other instances of delay as a challenge they face.

Project cancellations Not many cited the concern of cancellations of surveys as a challenge faced amidst Covid-19. Indeed, the only respondent to do so recounted that as early as February 2020, he received a request to attend to damaged container reefers importing mackerel at the Port of Tema,
Ghana. The vessel was not due for arrival until the second week of March as cargo got transferred unto the Maersk vessel bound for Ghana. Subsequently, as Covid-19 concerns gained prominence, the principal did not follow-up with the request for the damage claim survey of the reefer containers.

The need for innovation eminent Some respondent described the need for innovation as essential going forwardparticularly those within large survey companies. According to them, the Covid-19 health crises remain danger-risking the life of the attending surveyor on the survey site, worse of is the numerous restrictions in place - a sentiment expressed by some. This problem was evident in the cases highlighted above. All respondents attest there is a need for continuous innovation in product delivery. As one puts it; 'Covid-19 has highlighted the inherent risks in the industries we operate in and has shown us that we need to be at the forefront with innovation to deliver our service more effectively and robustly. To adapt to regulations and policies.' This statement goes to suggest that the future of the industry lies inaccessible innovation, be it technological (like the use of remote surveys (DNV GL n.d.), remote sensor drones applications) or social innovations such as limiting attendance to certain types surveys.

\section{Background of the case studies: marine warranty survey attendances observed}

The study area focuses on the African maritime industry for qualitative interviews, whereas sites chosen for direct site observation take into account time spent on marine vessels, hotels lodged at, the locations of such vessels, port facility and assets, and covered under the MWS scope of work (SOW). In this case, given that the two significant operations studied occurs in Nigeria and Ghana, respectively, at a varying time, the scope of the study area is within the West African subregion. Ordinarily, the location of the home (residence) of the survey is a factor in this study - influencing travel time and lodging requirement. However, the focus is hard more on seaport facility and marine vessels and assets. The primary and secondary sites of the study are the Takoradi port (see Fig. 2) and ABO oil field (see Fig. 3) in Nigeria, respectively, and this thus is described in the following paragraphs.

The seaport of Takoradi, located at latitude $4^{\circ} 532^{\prime} \mathrm{N}, 1^{\circ}$ $345^{\prime} \mathrm{W}$ and $225 \mathrm{~km}$ away from Accra-commissioned for business in 1928 in the western part of Ghana, is currently undergoing a significant expansion works (as seen in Fig. 2) amid Covid-19.

The serves vessels en route to and from Europe, America, and Asia besides the domestic and sub-regional comprehensive trade for the three Sahelian landlocked economies of Burkina Faso, Mali, and Niger (Ghana Ports and Harbour Authority, GPHA 2020c). In 2019, GPHA reported that the 


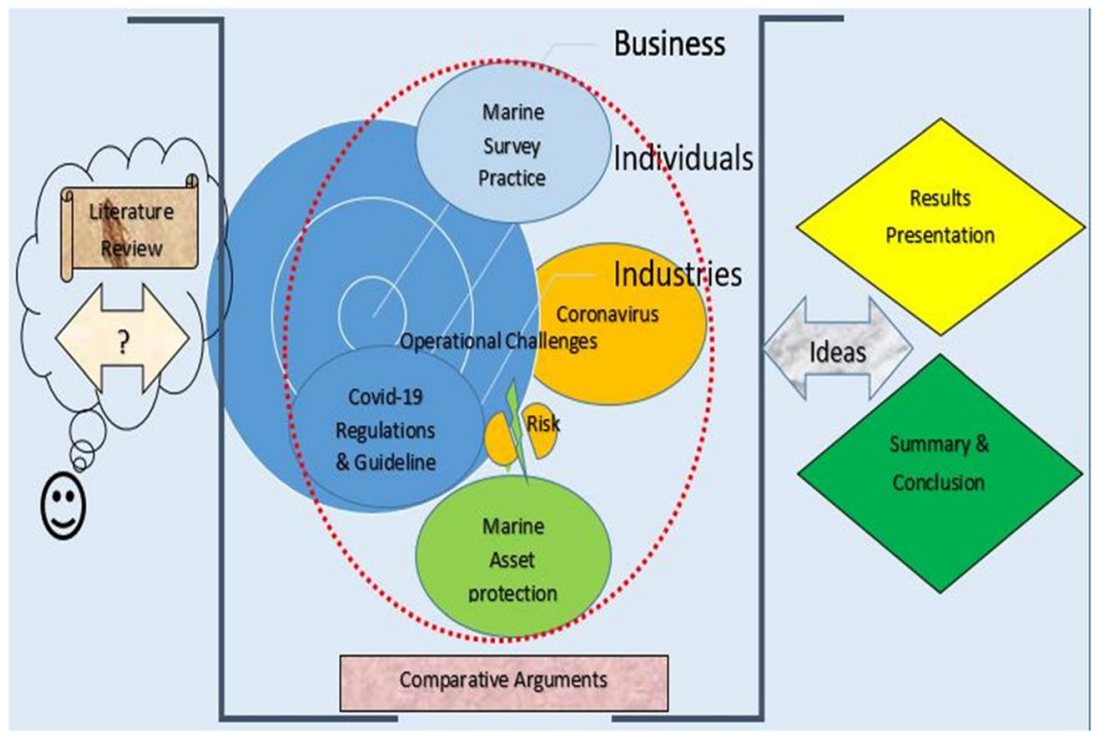

Fig. 2 Analysis flow chart

port handled $38 \%$ domestic seaborne traffic to $75 \%$ exports; however, only $17 \%$ of domestic seaborne imports. Manganese, bauxite, clinker, wheat, bulk and bagged cocoa, quicklime, containerised cargo, equipment for the mining, as well as the oil and gas industry are the major commodities handled. Leading shipping lines handled Maersk, MSC, Grimaldi, Delmas, and CMA CGM extending the trading influence of our clients globally. The 2007 oil discovery about 70 nautical miles from the port continuous to contribute significantly to Ghana's economy. This development has grown with new production sites and discoveries. The need for strategic logistical support bases for the offshore exploration and production of oil and gas has increased; likewise, port calls by vessels thus from a pre-annual oil discovery figure of 600 to 1628 as at the end of 2019 (GPHA 2020b). This rapid rise set in motion service companies and expertise such as the MWS sort in the area. The secondary location for this study, the oil and gas field (seen in Fig. 3), was within the western part of the Niger Delta, Nigeria, within geographical water depth ranging from 350 up to $780 \mathrm{~m}$. The field consists of a subsea development - all connected to a common FPSO (CNS-NAE 2020). The researcher also took into account time spent on another offshore oil and gas field in Ghana, the Jubilee Oil field in the period of March and September 2020.

\section{The April 2020 case study: hydraulic leak subsea intervention-campaign attendance}

The subsidiary MWS company located in Nigeria received an inquiry from the client to provide an MWS attendance for a significant maintenance project campaign which was in its third phase. The client together with MWS company agreed on the period of MWS attendance - thus expected to last 5 days offshore and aboard MV Horizon Enabler. The vessel at the time was sheltered in Ghana's waters (Port of Takoradi). The marine vessel was previously engaged on early campaigns on the same project. Due to her location at the time, the MWS company and the client agreed on assigning a nearby surveyor - bearing in mind health concerns, the ongoing localised restrictions in Ghana and Nigeria, and public order
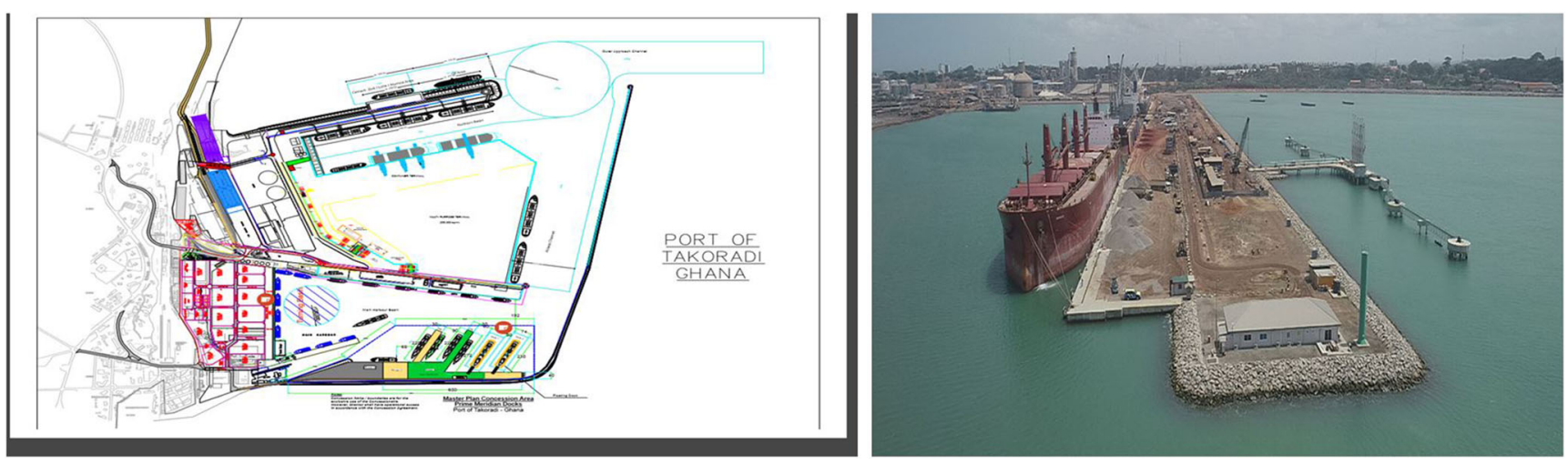

Fig. 3 Architecture plan and digital image of newly constructed bulk carrier terminal with Takoradi Harbour 
requirement. The MWS company proceeded to assign an MWS who subsequently handed a scope of work (SOW) instructions - accompanied with the required documents. The task overall was a 'Witness of Subsea Leak Investigations Test and Issue Statement of Fact'. The attending MWS, allocated a day's travel, a two-period standby in a hotel before mobilisation onboard the marine vessel, followed by sailaway to the designated offshore location on the offshore field (Fig. 3).

The Covid restriction travel experience Operations commenced on April 7, which saw the attending MWS travel from home over $6 \mathrm{~h}$ to the standby location within Takoradi. This attendance was a period many nations were heightening travel restrictions, including Ghana and Nigeria. Ghana at the time had commenced lockdowns of the two significant economic capital. Takoradi remained functional with limited restrictions and with substantial public order mandates. The attending surveyor's home was also outside the lockdown regions of Greater Accra and Ashanti region. The situation impacted on the choice of the surveyor selected for the attendance - as most of the surveyors were resident in the capital Accra and Tema under lockdown. Travelling from home (in the city, Koforidua of Eastern region) to Takoradi was without extreme challenges. Concerns arose as a result of the time at which instructions to travel came, as well as the choice of access roads available (see Fig. 4). The lockdown meant no commuting vehicle was allowed in or out of the lockdown cities within the lockdown regions.

From the map (in Fig. 4), one can identify the primary travel route from Koforidua and Takoradi, which goes through the Greater Accra region. The road from Koforidua links to the Trans-West Africa highway, N4 bound to both countries (e.g. Burkina Faso, Mali) north of Ghana and those at the west (e.g. Ivory Coast). In this case, the surveyor was forced to circumvent the Greater Accra region using both feeder and urban road access routes of towns and villages north of the lockdown region. The situation prolonged the 6-h journey by three more hoursarriving at the hotel as late as 02:00 am (GMT). Access to public transport was not without a challenge as well.

The Covid restriction mobilisation experience and the exercise of management change At the hotel, despite the late arrival, Covid-19 personal hygiene protocols were observed. The surveyor was assigned a room where MWS remained on standby and self-quarantined for two conservative days - awaiting vessel's arrival at the quayside for mobilisation. On day two of standby, MWS received instructions to demobilise as soon as practicable (ASAP). This development update followed management of change exercised by the client and consented by MWS company to abrogate the contract of the marine vessel. It is unclear what warranted the change; however, it did appear to a result of the evolving restriction and policy situation updates in the MWS SOW country, Nigeria. A new vessel based in Nigeria at the time was engaged, and another MWS (locally based) was assigned to oversee the task.

\section{The June 2020 case study: barge towage from Ghana to Angola operation}

Again, the MWS company received an inquiry from their client to undertake an MWS suitability survey (S.S.), complete a sailaway checklist of the tug boat, and then possibly witness the towage connection before sailing from Ghana to another African country. The client, in agreement with the MWS company, subsequently appointed the attending surveyor within Ghana. The survey was to last for a day with an additional appointed travel period of half a day. The Takoradi port was the precise shelter for both the cargo barge and assigned tow (tug) boat.

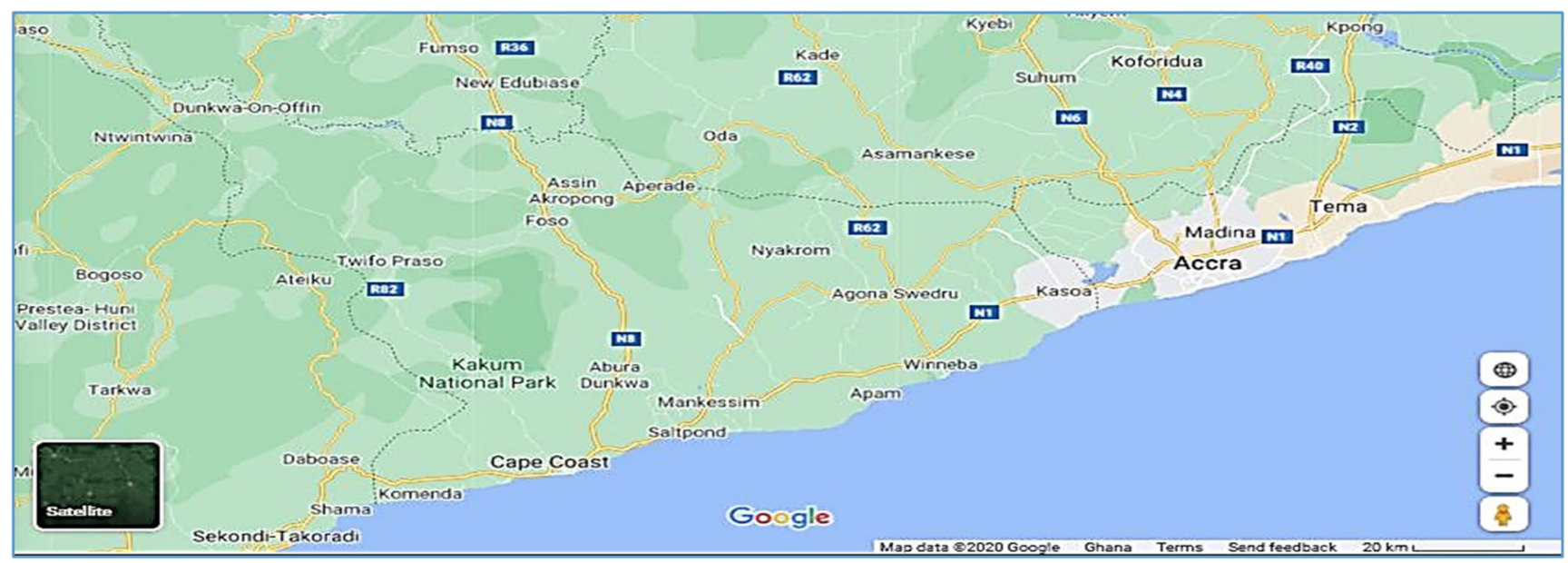

Fig. 4 Road network from Koforiua to Takoradi. Courtesy; Google Satellite (2020) 
The travel experience to the attending MWS site The surveyor complied with the Covid-19 travel protocols of MWS Company-departing from home, a 6-h drive away from the city of Takoradi. The Greater Accra region at the time remained under lockdown as case counts continued, and also begun to spread to other regions slowly. The travel was without a challenge in terms of delays with public transport. Though the Covid-19 public mandate had slashed the number of passenger intake by half to comply with social distancing, there were fewer commuters making travels. The MWS subsequently arrived in Takoradi by 12:00 pm (GMT) and immediately commenced operation.

\section{The MWS attendance experience on the backdrop of Covid-19}

The previous incidence of a delay from earlier MWS operation caused the appointed surveyor to travel ahead of time which was a day earlier to the expected survey. While on the way, updates from client representative suggested the survey time scope had imminently changed, and therefore survey was to commence on arrival. This situation was a surprise; however, the MWS was delighted to oblige. On arrival in Takoradi, MWS made way to the client's yard within the port, where there was a short 'meet and greet' encounter while complying with Covid-19 protocols of the Takoradi Port, client, and the MWS company. This exercise was with an HSE induction (protocol specified by work instruction shown in Fig. 5 of Appendix); after which, the surveyor got ready for the S.S. inspection (guided by company HSE policy, and Covid-19 protocol found in Field Work HSE Handbook ${ }^{5}$ ). The weather generally was favourable with sunshine all through the day. First to be inspected was the barge given that it remained docked at the immediately accessible quayside. The MWS boarded the barge at the quaysidecommencing inspection 45 min after arrival in the port. As inspection progressed steadily into an hour, the surveyor received a word from the client's representative (rep). It was an information and request indicating that the port had given clearance for the tug boat to approach quayside. The request was for the surveyor to suspend the S.S. inspection on the barge and attend to the tug boat for completion of the sailaway checking list — given that the wharf would be unavailable by midnight. By then, the tug boat would be out in the anchorage until tow connection commences. The sailaway attendance was completed within the stipulatedallowing the tug to sail out of the harbour at nightfall. The S.S. on the barge was scheduled for the next day as the surveyor returned to designated hotel for the night.

The S.S. attendance and bad weather amid Covid The second day of the survey was early upon arrival at the yard in the port on a Sunday morning. The skies were relatively straightforward

\footnotetext{
${ }^{5}$ Field Work HSE Handbook with Document No. DMSO-13-2-A1 Rev.01, 2016-04-27 is the principal guide of the MWS which effectively work alongside the attending site HSE policy. Exhibit of the book by cover is in Figure 6 of the Appendix.
}

with favourable levels of humidity. The surveyor boarded the barge after 30 min on arrival accompanied by client's rep as inspection commenced. The S.S. inspection progressed steadily until 08:30 when the slight cloud activity began to occur. This cloud began the orchestration of intermittent rainfalls all through the day. Subsequently, the inspection process was interrupted not less than three conservative times before completing the suitability survey by midnight (GMT) midday. The rains in effect got the nose masks wet and uncomfortable to use.

The witness of tow connection before sailaway amid Covid The third day saw the surveyor closeout on the S.S. conducted before the commencement of tow operation. This closeout was particularly vital as it determines for issuing the COA that morning of the departure. With no outstanding issues to be resolved that was eminent to the safety of the operations and tow from Ghana to Angola, MWS issued and signed on the COA which commenced the tow connection an hour later. With a short toolbox talk of critical personnel involved and aboard the barge, the tow commenced with the approach of two harbour tugs - pulling stern and bow respectively. At this time, harbour pilots had boarded four vessels involved. The towboat remained standby location in breakwaters for the barge. As time progressed, the barge successfully connected with the towboat. Personnel aboard the barge subsequently demobilised unto the pilot boat which came alongside in harbour - thereby commencing the towage of the cargo barge. The MWS on completion of the task subsequently demobilised and returned home. Figures 7 and 8 in the Appendix depicts one of the MWS operation attendance.

From both attendances, the challenge of the Covid-19 restrictions was brought to bear on the attending surveyor not only on the site of attendance but also on transportation and lodging comforts of the attending surveyor. This conditions did not, however, impact on the quality of work of the attending surveyor whose conduct was professionally executed all through the period. Like a soldier, marine surveyors deem their job as life and death and are ever-ready to make all necessary sacrifices to ensure a continuum of safety and risk-free operation in the marine industry.

\section{Summary, conclusion, and recommendations}

\section{Summary}

The study found that all respondents demonstrated a high level of awareness for the protocols and health risks they faced during site attendances. They were, however, not discouraged from site attendances - given their commitment to working with protocols. None of the respondent at the time of the interview had tested positive since the onset of the pandemic. Some did note, however, that they had worked alongside vessels whose crew previously tested positive. According to them, this did not in any way compromise their ability to perform during attendance. Again, respondents 
indicate given the fact that maritime transport remains the lifeline of trading and supplies during the pandemic, a global declaration given seafarers, and associated staff such as the marine surveyors the title of essential worker status would go a long way to help in their operations. For the attendances observed in both case studies referred to, at Takoradi Port, located in the western region of Ghana was the sheltered port for the subsea installer vessel for the intervention campaign, the cargo barge, and tug boat assigned for the towage - all occurring between the period of April and June 2020. These were periods that reflected heightened restrictions locally and on a global scale. With significant transport industries like aviation halted due to closure of primary and almost every airports, seaport, and land borders, maritime transport and operations of vessels remained critical and a lifeline to the world. The offshore oil field installations also depended on it for the much-needed supplies and for repair works in order to avert major environmental, human, and animal life catastrophes. These two reasons essentially spared the MWS services identified in both of the cases presented in the earlier paragraphs. Despite the spread of the virus, and the restrictions that were put in place by the individual government in complying with the WHO Covid-19 guidelines, it was also clear a total halt of activities for individuals, company, nation-states, and the world at large was never an option within the limitations aimed at ending its spread. Such consequences would have been catastrophic and could easily equate to the predicted fallout of unaddressed concerns of climate change. In other words, amid Covid-19, oil wells remained life, subsea installation systems remained life and needed maintenance, hospitals need an adequate supply of power from powerplants beside consumables, fire tenders, and ambulances which are all engaged in emergency response all today heavily on fossil fuel. Marine vessels, offshore installations, and shoreside facilities have also been at the forefront (Lloyd's Register 2020) of the Covid-19 fight - providing the essential energy commodity to power innovation, healthcare, and economic sustenance. The challenges experienced due to the spread of Coronavirus is identified in an earlier section and classified into (a) the risk to health crises as the spread continuous with not advance cure insight and (b) the restrictive regulations crises forcing socioeconomic activities to shrink world over. The impact of the Covid-19 health and regulation crises as mentioned above has led to the economic fallout (ECOWAS 2020a) in terms of loss of business, high-cost to doing business, and the massive rush for innovative ways of staying in business. The latter suggests some semblance of hope for marine surveyors determined to ride the tide.

\section{Conclusion}

The study, therefore, concludes noting the Covid-19 crises is still an ongoing concern as the government, scientists, and business leaders face towards providing both therapeutic and vaccine treatment. Unfortunately, these crises also align with major democratic electoral calendars across the world, including that of Guinea, Ghana, and the USA. This trend means ending the spread rides close to impossible - the reason most countries had to open ahead of cure. MWS businesses like any other businesses in the maritime industry have to be proactive and innovative - having in mind policies and the regulatory guideline of their countries of operation. In Ghana, reiterating Maritime Law Consultant, and CEO Ghana Chamber of Shipping, Dr Kofi Mbiah, who is quoted as saying, 'If you listen to the doomsayers, who say if nothing is done fast, it means global GDP is going to drop by $0.5 \%$, and that means we are talking 1 trillion dollars in terms of loss, and that is significant. That would certainly spin us into a recession' (GPHA 2020a). In other words, the challenge remains, and it is incumbent on businesses to be innovative going forward.

\section{Recommendations}

The following are a few recommendations that would ensure a robust, practical, and continuous operation in potential future pandemics.

(a) Importation of technology into product delivery for businesses: service delivery in light of access restriction means services carried out remotely. The use of technology, in this case, can be achieved in two way. Thus, there was the use of cloud servers, which is the fundamental aspect of service that involves the review of documents carried out remotely. Documents can be transmitted from the site by client rep to aid this process. This remote service, therefore, will limit the time spent on-site if the need to visit such places is inevitable. Drone technology is a fast-growing industry and does offer survey capabilities in ways use to riding this pandemic.

(b) Social re-engineering of innovation by businesses: having a competent and well-trained professional located in vantage areas does ensure the sustainability of the business. Often, companies are quick to set up in major capital cities while neglecting the rest of the surrounding cities. The Covid-19 crises suggest that business networking among other businesses and professionals tends to ensure client satisfaction even when the parent company located in the vicinity of a lockdown city or country.

(c) Introduction of innovative insurance packages: insurance packages that are all-encompassing in order to keep companies afloat have become a necessity following the outbreak. Such an insurance package should be a living premium and should encourage innovation from businesses in order to benefit from such funding to keep afloat.

Further studies are required in the area in order to properly ascertain the extent of the impact on the health of surveyors and also business, if a future pandemic is going to have holistic remediation within the maritime industry, with minimal crises unlike that witness in the Covid-19 crises. 


\section{Appendix. A sample of work instruction, field guide HSE requirement, and images of field observations during attendances}

\begin{tabular}{|c|c|c|c|c|c|c|c|c|c|}
\hline \multicolumn{10}{|c|}{ LOCATION AND CONTACT } \\
\hline \multicolumn{2}{|c|}{ Other Information } & \multicolumn{8}{|c|}{ Further details on the attendace will follow with specific emails. } \\
\hline \multicolumn{10}{|c|}{ ACTIONS REQUIRED } \\
\hline \multicolumn{2}{|c|}{$\begin{array}{l}\text { Aasionment } \\
\text { Detalts } \\
\text { (Definod Scope } \\
\text { and Procodures) }\end{array}$} & \multicolumn{8}{|c|}{$\begin{array}{l}\text { Witness Leak Investigations of ABO field low pressure hydraulic control lines. } \\
\text { Issue Statement of Fact following leak tests. } \\
\text { PM will provide all the relevant documentation to enable MWS to follow leak } \\
\text { tests. }\end{array}$} \\
\hline \multicolumn{2}{|c|}{$\begin{array}{l}\text { Document(s) } \\
\text { Reviewed and } \\
\text { Location }\end{array}$} & \multicolumn{8}{|c|}{ As per email. } \\
\hline \multicolumn{2}{|l|}{$\begin{array}{l}\text { Codes and } \\
\text { Guidoines } \\
\text { Applicabile }\end{array}$} & \multicolumn{8}{|c|}{ DNVGL-ST-NOO1 } \\
\hline \multicolumn{2}{|c|}{$\begin{array}{l}\text { Cons } \\
\text { (Nos. and Detsis) }\end{array}$} & \multicolumn{8}{|l|}{$N / A$} \\
\hline \multicolumn{2}{|l|}{$\begin{array}{l}\text { Ohocidiste } \\
\text { Required }\end{array}$} & \multicolumn{8}{|l|}{ N/A } \\
\hline \multicolumn{2}{|c|}{$\begin{array}{l}\text { Additional Detalls } \\
\text { A Information }\end{array}$} & \multicolumn{8}{|c|}{\begin{tabular}{|l|} 
Please submit all receipts (flight taxi, hotel, food etc) for invoicing, \\
Timesheet (travel/attendance days) to be signed by CPY weekly (on Sunday).
\end{tabular}} \\
\hline \multicolumn{2}{|c|}{ HSE and PPE } & \multicolumn{8}{|c|}{ As per DNV GL requirements and Client/Site requirements. } \\
\hline \multicolumn{2}{|c|}{\begin{tabular}{|l|} 
Sosodsl HSE \\
Considerotions
\end{tabular}} & \multicolumn{8}{|l|}{$N / A$} \\
\hline \multicolumn{10}{|c|}{ DELTVERABLES } \\
\hline $\begin{array}{c}\text { Poat } \\
\text { Surver } \\
\text { Summary }\end{array}$ & $\square$ & $\begin{array}{l}\text { Formal } \\
\text { Report }\end{array}$ & $\mathrm{s}$ & $\begin{array}{l}\text { Statement } \\
\text { of Focts }\end{array}$ & $\approx$ & $\begin{array}{l}\text { w/Captioned } \\
\text { Photos }\end{array}$ & $\square$ & $\begin{array}{l}\text { Surveyor's } \\
\text { Log }\end{array}$ & 8 \\
\hline $\begin{array}{l}\text { Certificate } \\
\text { of } \\
\text { Approval }\end{array}$ & 口 & $\begin{array}{l}\text { Statement } \\
\text { of } \\
\text { Facts }\end{array}$ & 口 & $\begin{array}{l}\text { Completed } \\
\text { Checklats }\end{array}$ & 마 & $\begin{array}{l}\text { Prelasd } \\
\text { Penetration } \\
\text { Record }\end{array}$ & $\square$ & $\begin{array}{l}\text { Recommendations } \\
\text { List }\end{array}$ & 口 \\
\hline
\end{tabular}

Fig. 5 Sample Work instruction in MWS practice

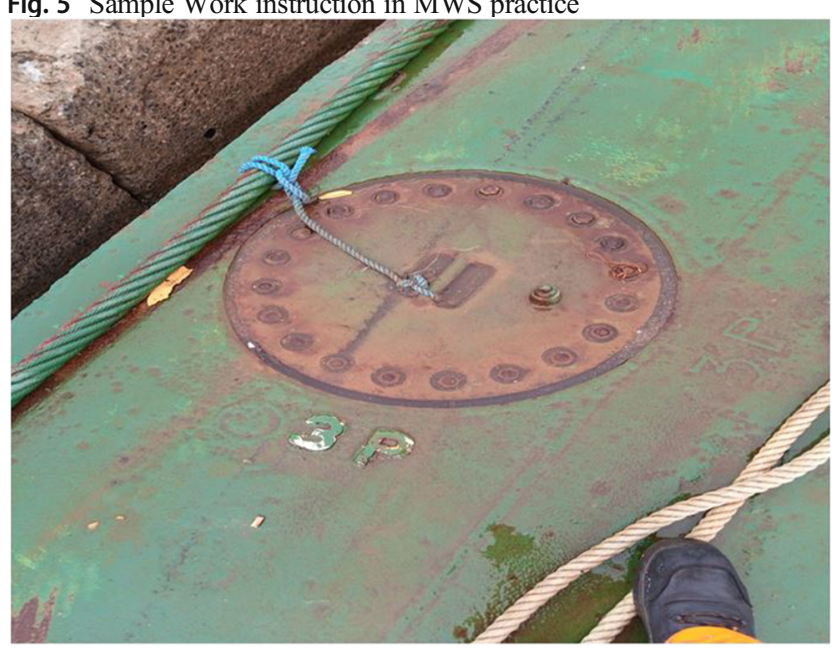

Fig. 7 MWS inspecting manhole cover during SS
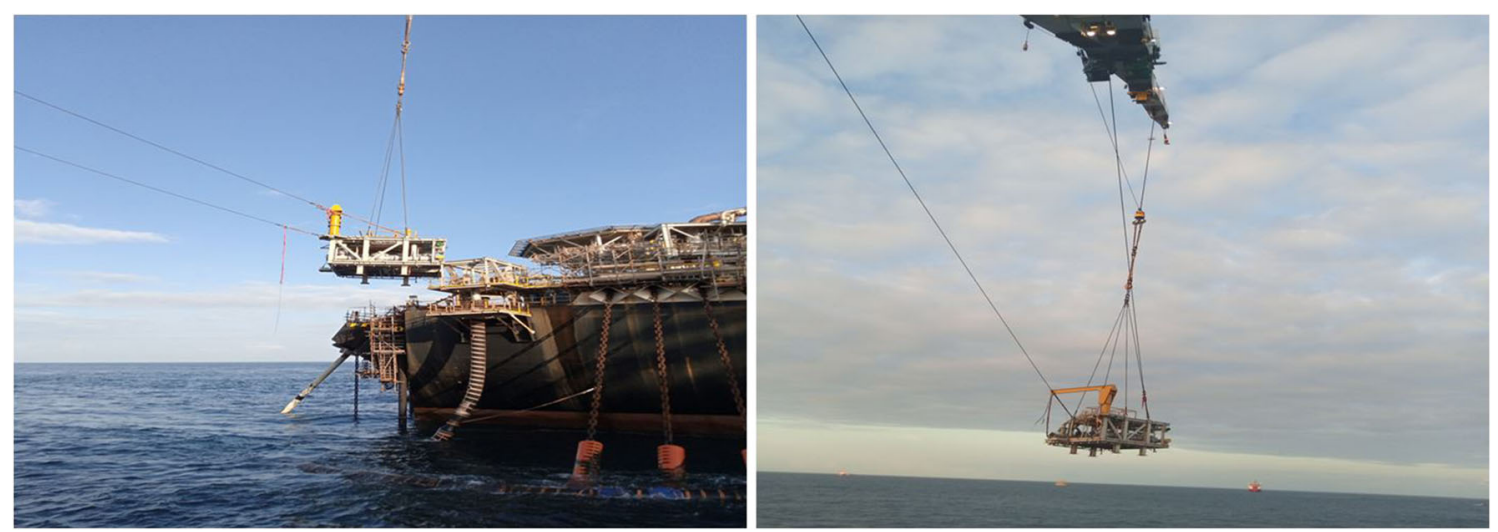

Fig. 9 Installation operation of a pegging skid on FPSO unit offshore 
Supplementary Information The online version contains supplementary material available at https://doi.org/10.1007/s40152-021-00220-7.

Acknowledgements Our most excellent acknowledgement goes to affiliate institutions particularly DNV Oil and Gas/ Grassfield Maritime Consultants Nigeria, family and friends who supported us through this study in diverse ways. We wish to thank the surveyors who contributed to this study with their enormous experience and thoughtfulness. Our final but not the least thanks go to the University of Selinus, Dr. D. Y. Patil Vidyapeeth, Pune (Deemed to Be University), and the very institutional affiliates of the expert surveyors for letting this study be a success. We give our final thanks to the most supreme God for seeing us through this study.

\section{Code availability Not applicable}

Disclaimer The authors do note here that their judgement may or may not have been impaired by their affiliations with notable MWS companies subject to the study.

\section{Author contribution Not applicable}

Funding Overall funding which included travels, hotels, and administrative costs were the authors' own expense. The authors wish to emphasise here that there were no secondary funds from any source.

Data Availability Interviewed responses are available; however, confidential material cannot be disclosed at this time

\section{Declarations}

Conflict of interest The authors declare no competing interests.

\section{References}

Alpert, P.T., S.K. Miller, H. Wallmann, R. Havey, C. Cross, T. Chevalia, C.B. Gillis, and K. Kodandapari. 2009. The effect of modified jazz dance on balance, cognition, and mood in older adults. Journal of the American Academy of Nurse Practitioners 21 (2): 108-115.

ASME. 2004. The Role of Marine Surveyor and Their Requirement for Selected Items. Retrieved at; http://citeseerx.ist.psu.edu/viewdoc/ download?doi=10.1.1.656.3438\&rep=rep1\&type=pdf.

BBC. 2020. Covid: Workers taken off rigs after positive tests. https:// www.bbc.com/news/uk-scotland-north-east-orkney-shetland54537740 .

CNS-NAE. 2020. ABO Central Subsea Hydraulic Loss Emergency Subsea Intervention- Campaign 3. Unpublished Document, CNS Marine, Nigeria.

DNVGL. 2020. Offshore Wind. https://www.dnvgl.com/powerrenewables/themes/offshore-wind/index.html.

DNVGL. n.d. Remote Surveys for Fleet in Service. https://www.dnvgl. com/services/remote-surveys-for-fleet-in-service-142702\#: :text= DNV\%20GL\%20offers \%20remote\%20surveys, surveyor\% 20travel\%20to\%20the\%20vessel.

Dolven, T. 2020. No Information. No Way off. 100,000 Crew Members Remains in Cruise Ship Limbo for Months. Available online: https:// www.miamiherald.com/news/business/tourism-cruises/ article242565281.html.

ECOWAS. 2020a. ECOWAS Guidelines Harmonisation and Facilitation of Cross-Border Trade and Transport COVID-19. https://www. tralac.org/documents/resources/covid-19/regional/4091-ecowas- guidelines-harmonisation-and-facilitation-of-cross-border-tradeand-transport-covid-19-june-2020/file.html.

ECOWAS. 2020b. ECOWAS Ministers Validate Reports on Ease of Business and CoronavirusControl. https://www.ecowas.int/ ecowas-ministers-validate-reports-on-ease-of-business-andcoronavirus-control/.

Ellinor, T. (2013). Updated Version Guidelines and Grading Criteria for Thesis Projects Department of Business Administration. https:// www.bibliotek.hv.se.

Eoin O'Cinneide. 2020. Dozens test positive for Covid-19 on vessel working at Tullow's Jubilee field off Ghana. https://www. upstreamonline.com/coronavirus/dozens-test-positive-for-covid-19on-vessel-working-at-tullows-jubilee-field-off-ghana/2-1-817427.

GARDAWORLD. 2020. Ghana: Wearing of Face Mask Mandatory in Public in Greater Accra. www.garda.com.

Ghanahealthservice.org. 2020. First confirmed COVID-19 cases in Ghana 12 Mar 2020. https://www.ghanahealthservice.org/covid19/ downloads/covid 19 first confirmed GH.pdf.

Ghana Ports and Harbour Authority, GPHA. 2020a. Experts Predict An Economic Recession If Coronavirus Pandemic Exceeds Projected Timelines. https://ghanaports.gov.gh/Media/news-details/84/ EABLQJZL/EXPERTS-PREDICT-AN-ECONOMICRECESSION-IF-CORONAVIRUS-PANDEMIC-EX...3/3.

Ghana Ports and Harbour Authority, GPHA. 2020b. Our History and Future. https://www.ghanaports.gov.gh/page/index/20/55QF2TKE/ Our-History-and-Future.

Ghana Ports and Harbour Authority, GPHA. 2020c. Welcome Message. https://www.ghanaports.gov.gh/page/index/15/EXKGB1KA/ Welcome-Message.

Google Satellite. 2020. Ghana Map Road Network. Retrieved from; https://www.google.com/maps/search/ghana+map+road+ network/@5.6784738,-1.4565539,9z.

Greg Naterer. 2020. In the midst of coronavirus crisis lies great opportunity for Canada's offshore oil and gas industry. https:// theconversation.com/in-the-midst-of-coronavirus-crisis-lies-greatopportunity-for-canadas-offshore-oil-and-gas-industry-139638.

GWEC - Global Wind Energy Council. 2020. Opportunities and challenges after COVID-19 for global Offshore Wind Industry. https:// gwec.net/opportunities-and-challenges-after-covid-19-for-globaloffshore-wind-industry/.

Haynes, Boone, Andreas Dracoulis, Jonathan Morton. 2020. COVID-19 and its impact on Offshore Construction. https://www.offshore-mag. com/business-briefs/coronavirus/article/14178564/haynes-andboone-covid19-and-its-impact-on-offshore-construction.

Joint Rig Committee Rig Move Code of Practice (COP). 2016. Joint Rig Committee (JRC). https://www.lmalloyds.com/LMA/Underwriting/ Marine/JRC/scope jrc.aspx.

KPMG-Ghana. 2020. Ghana- Covid-19 - Related Travel Restrictions and Safety. https://home.kpmg/xx/en/home/insights/2020/03/flashalert-2020-094.html

Learn.org. 2020. What Is Marine Surveying? https://learn.org/articles/ What is Marine Surveying.html\#: :text=Marine\%20surveying\% 20 is $\% 20$ the $\% 20$ practice,an $\% 20$ expert $\% 20$ witness $\% 20$ in $\% 20$ court.

Lee Hong Liang. 2020. Shipping Has Reasons to Be Optimistic despite Serious Challenges https://www.seatrade-maritime.com/containers/ shipping-has-reasons-be-optimistic-despite-serious-challenges.

Lloyd's Maritime Institute. 2018. Introduction to Marine Survey Profession: Module 1. Geneva, Switzerland: Lecture Handout, Lloyds Maritime Institute.

Lloyd's Register. 2020. Long-term ambitions remain for offshore, despite challenges from COVID-19. https://www.lr.org/en/insights/articles/ long-term-ambitions-remain-for-offshore-despite-covid19challenges/.

Maekelae M.J. 2020. Equity and Human Right Commission: Covid-19 Restrictions and the Effect on Human Rights. http:// equityhumanrights.com. 
Marcus Hand. 2018. World trade growth flattened in the second quarter, but despite the threat of a US-China trade war prospects remain positive according to Global Kuehne + Nagel Indicators (gKNi). https://www.seatrade-maritime.com/americas/world-trade-outlookpositive-despite-trade-war-threat.

McCauley Douglas, Kristian Teleki, Gloria Fluxa Thienemann. 2020. 8 ways to rebuild a stronger ocean economy after COVID-19. https:// www.weforum.org/agenda/2020/05/how-to-build-a-bluer-oceaneconomy-after-cobid-19/.

Ministry of Health, Ghana. 2020. President Akufo-Addo Addresses Nation On Measures Taken By Gov't To Combat The Coronavirus Pandemic. https://www.moh.gov.gh/president-akufoaddo-addresses-nation-on-measures-taken-by-govt-to-combat-thecoronavirus-pandemic/.

MyJoyOnline. 2020. 11,657 jobs lost due to Covid-19 - Employment Minister revealshttps://www.myjoyonline.com/news/11657-jobslost-due-to-covid-19-employment-minister-reveals/.

Radic, A., M. Lück, A. Ariza-Montes, and H. Han. 2020. Fear and Trembling of Cruise Ship Employees: Psychological Effects of the COVID-19 Pandemic. International Journal of Environmental Research and Public Health 17 (18): 6741.

Sackey, Anthony Djaba, and Benjamin Lantei Lamptey. 2019. Activities of Local Fishermen Within Ghana's Offshore Construction Fields, Impact on Operations- Polar Onyx Experience. Regional Maritime University Journal 6 Accra Ghana.

Sau, A., and I. Bhakta. 2019. Screening of anxiety and depression among seafarers using machine learning technology. Informatics in Medicine Unlocked 16: 100228.

STA Law Firm. 2020. Overview: Impact Covid-19 on the Shipping and Maritime Industry. https://www.stalawfirm.com/en/blogs/view/ covid-19-on-shipping-and-maritime-industry.html.

The International Maritime Organization, IMO. 2020. 400,000 seafarers stuck at sea as crew change crisis deepens https://www.imo.org/en/ MediaCentre/PressBriefings/Pages/32-crew-change-UNGA.aspx.

The John Hopkins University, The John Hopkins Hospital, and the John Hopkins Health System. 2020. What is Coronavirus? https://wwwhopkinsmedicine-org.cdn.ampproject.org/v/s/www. hopkinsmedicine.org/health/conditions-and-diseases/coronavirus?

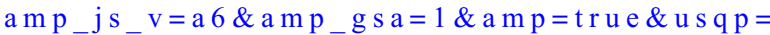
mq331AQFKAGwASA\%3D\#aoh=16039674132907\&referrer= https $\% 3 \mathrm{~A} \% 2 \mathrm{~F} \% 2 \mathrm{Fwww}$.google.com\&amp_tf=From\%20\%251\% $24 \mathrm{~s} \&$ ampshare $=\mathrm{https} \% 3 \mathrm{~A} \% 2 \mathrm{~F} \% 2 \mathrm{Fwww}$.hopkinsmedicine.org $\%$ 2Fhealth $\% 2$ Fconditions-and-diseases $\% 2$ Fcoronavirus.

The Maritime Standard (TMS). 2020. Offshore Oil And Gas Sector Adapting Well To Covid-19 Challenges. Webinar Panel Discussion. https://www.themaritimestandard.com/offshore-oiland-gas-sector-adapting-well-to-covid-19-challenges/.

Thetius. 2020. Maritime Technology Initiatives Supporting The Industry Covid-19 response. Retrieved at https://thetius.com/maritimetechnology-initiatives-supporting-the-industry-covid-19-response/.
TÜV-Rheinland. 2013. Marine Warranty Survey Services. https://www. tuv.com/media/corporate/industrial_service/Marine_warranty_ survey-TUV_Rheinland.pdf.

U.N. Chronicle. 2020. Innovation for a Sustainable Ocean amid theCOVID-19 Pandemic: Impacts on Kenya's Marine and Coastal Environment. https://www.un.org/en/un-chronicle/innovationsustainable-ocean-amid-covid-19-pandemic-impacts-Kenya'smarine-and-coastal.

US CDC. 2020. Public Health Responses to COVID-19 Outbreaks on Cruise Ships - Worldwide, February-March 2020. Weekly / March 27, 2020 / 69(12);347-352. https://www.cdc.gov/mmwr/ volumes/69/wr/mm6912e3.htm.

U.S. Embassy in Ghana. 2020. COVID-19 in Ghana. https://gh. usembassy.gov/ghana-covid-19-information/.

UNCTAD. 2019. Review of Maritime Transport 2019 - UNCTAD. https://unctad.org/en/PublicationsLibrary/rmt2019_en.pdf.

United Nations Conference on Trade and Development (UNCTAD). 2020. Covid-19: A 10-Point Action Plan To Strengthen International Trade And Transport Facilitation In Times Of Pandemic. Policy Brief No. 79.

Whiting, K. 2020. Stuck at sea: How to save the world's seafarers and the supply systems they support stuck at sea: How to save the world's seafarers and the supply systems they support. https://www. weforum.org/agenda/2020/06/shipping-seafarers-covid-19-mentalhealth-supply-systems/https://www.weforum.org/agenda/2020/06/ shipping-seafarers-covid-19-mental-health-supply-systems/.

WIKIPEDIA. 2020. COVID-19 pandemic on cruise ships. https://en. wikipedia.org/wiki/COVID-19_pandemic_on_cruise_ships.

World Economic Forum. 2020. How COVID-19 Is Impacting On Sea Crew And What Can Be Done. https://www.weforum.org/agenda/ 2020/06/shipping-seafarers-covid-19-mental-health-supplysystems/.

World Health Organisation, WHO. 2020a. Coronavirus Disease (COVID 19) Weekly Epidemiological Update and Weakly Operational Update. https://www.who.int/emergencies/diseases/novelcoronavirus-2019/situation-reports.

World Health Organisation, WHO. 2020b. Update WHO recommendations for International Traffic in relation to Covid-19 Outbreak. https://www.who.int/news-room/articles-detail/updated-whorecommendations-for-international-traffic-in-relation-tocovid-19outbreak.

World Health Organization, WHO. 2020c. Episode \#2 - SARS-CoV-2. https://www.who.int/emergencies/diseases/novel-coronavirus2019/media-resources/science-in-5/episode-2.

Publisher's note Springer Nature remains neutral with regard to jurisdictional claims in published maps and institutional affiliations. 